\title{
Integrating the Landscape Vulnerability into Developing Liveable Rural Places: A Framework for Rural Landscape Vulnerability Evaluation from Human-natural Perspective
}

Tingting YU, Harbin Institute of Technology, Key Laboratory of Cold Region Urban and Rural Human Settlement Environment Science and Technology, Ministry of Industry and Information Technology, China

Hong LENG (Corresponding Author), Harbin Institute of Technology, Key Laboratory of Cold Region Urban and Rural Human Settlement Environment Science and Technology, Ministry of Industry and Information Technology, China

Yue WU, Harbin Institute of Technology, Key Laboratory of Cold Region Urban and Rural Human Settlement Environment Science and Technology, Ministry of Industry and Information Technology, China

\begin{abstract}
According to the formation of urban-rural structure in the process of global urbanization, rural area plays an important role in supporting the healthy, liveable environment in cities and villages. With the dual pressure of ecological environment change and rapid urbanization, the rural landscape has obvious problems, resulting in the degradation or even disappearance of rural landscape, and assimilation of rural civilization. In order to identify the rural landscape problems and reveal its formation mechanism, this paper proposes a specific framework to analyze the vulnerability indicators of rural landscape, to reflect the vulnerability of rural human-natural systems and explore the driving factors, and to propose corresponding planning strategies to cope with the vulnerability and shaping liveable places. The study focuses on the typical villages in representative county, located in Heilongjiang, China. Based on the vulnerability components of exposure, sensitivity and adaptation, we construct the evaluation index of rural landscape vulnerability, and use the comprehensive index method to calculate the vulnerability threshold of 12 typical villages, exploring the driving factors combining Factor Analysis and Principal Component Analysis. Further, the framework will propose a way to communicate with practitioners and policy makers on reducing or coping with landscape vulnerability. It can thus serve as a tool for targeting the implementation of policies and practices aimed at improving the liveable rural settlements environment in villages.
\end{abstract}

\section{Keywords}

Rural landscape vulnerability, Research framework, Vulnerability evaluation, Human-natural coupling system vulnerability, Liveable rural places 


\section{Introduction}

In the period of rapid urbanization, rural areas appeared a series of problems, including over-exploitation of construction land, excessive waste of energy, abandonment of cultivated land, inactivation of rural human settlement environment, which led to the degradation or even disappearance of rural landscape (Appleton K, 2002). A landscape vulnerability analysis of the rural settlements would identity the principle factors influenced the liveable village construction from human-natural perspective, with a quantitative evaluation (Peter Weißhuhn, 2019).

In 1990s, landscape vulnerability has been proposed to analysis probability of ecological landscape destruction (Hessburg P F, 1999), as a functional landscape attribute. This concept original aims at a fragile expression of landscape, which decreased landscape ecological stability (Drdos J, 2003). With the further research, landscape has been regarded as an important part of human-natural environment which is affected by social and economic development. These external disturbances can also have effect on the landscape vulnerability, and subsequently reduce quality of human life (Toro J, 2010). As a result, landscape vulnerability became a comprehensive attribute which expresses how many changes caused by exogenous factors, which was determined by the ecological environment, human land use activities and socio-economic development, reflecting the probability that landscape will change in a negative direction (Roberts AR, 1991). Generally, landscape vulnerability research has become a frontier scientific issue in interpreting the relationship between human and nature systems, exploring the operating mechanism of landscape systems under the disturbance of natural environment changes and human activities (Schneiderbauer S, 2004).

The research on rural landscape vulnerability has three obvious superiorities to solve the problems mentioned above. First, it analyses the rural landscape problems, and affected factors which lead to the vulnerability from the human-natural perspective. Second, it studies how to quantitively evaluate the rural landscape vulnerability, and how to scientifically analyze the driving factors. The third superiority is that rural planning strategies can be proposed according to the vulnerability evaluation, improving the construction of liveable villages with corresponding planning and management.

In viewing of these, this study is undertaken in order to present a conceptual framework for rural landscape vulnerability from the perspective of rural human-natural mechanism, according to the analysis of the appearance of rural landscape vulnerability in developing villages. We identify the spatial characteristics of 12 typical villages in the Northeast China Plain, and analyze the problems and driving mechanism using a landscape vulnerability evaluation model, which can support for selecting the optimum rural planning route to promote liveable environment. The goals of this study are listed as follows:

(1) Construct a framework for rural landscape vulnerability from the perspective of human-natural coupling system

(2) Construct the evaluation index and evaluation method of rural landscape vulnerability, and calculate the vulnerability thresholds of 12 typical villages

(3) Propose rural planning strategies and policies to cope with the landscape vulnerability, aiming to develop liveable rural places.

Furthermore, the process of establish a rural landscape vulnerability evaluation is applicable to the Beauty Village Construction in the new period, aiming to propose the resilience improvement alternatives for the maximum of appropriate protection and adaptive development, promoting the happiness of villagers. 


\section{Literature of Traditional Approach for Vulnerability Assessment}

With literature review in Scopus, we provide examples of definitions for landscape vulnerability (LV) and human-natural system vulnerability (HNSV) and focus on those methods that evaluate the vulnerable threshold or give results that can be used in ranking.

\subsection{Definitions of Landscape Vulnerability and Human-natural System Vulnerability}

When we searched the literature of vulnerability in Scopus, there were more than 60,000 hits of the single term "Vulnerability" in publication histories of >30 years (Scopus Content Coverage Guide, 2020). LV as a single term generates few publications and has been studied in combination with landscape fragmentation, agricultural landscape, or forest landscape, mostly in last 10 years. During the last years there has been an increasing attention to the HNSV to the threats of different types, like extreme climate events or land use changes. In attempts to distinguish the concepts, some definitions are listed in Table 1.

Table 1. Several examples of definitions.

\begin{tabular}{|c|c|c|c|}
\hline Term & Characteristics & Brief description of concept & Author \\
\hline $\begin{array}{l}\text { Landscape } \\
\text { Vulnerability }\end{array}$ & $\begin{array}{l}\text { discuss the future } \\
\text { condition } \\
\text { focus on changes of } \\
\text { landscape structure } \\
\text { focus on landscape } \\
\text { elements } \\
\text { focus on landscape } \\
\text { fragmentation }\end{array}$ & $\begin{array}{l}\text { an ability of landscape receptor to respond to } \\
\text { external pressures and stress with losing or } \\
\text { degrading its quality } \\
\text { Overlap of changes in land use with sensitive } \\
\text { ecological resources, on county scale } \\
\text { a valuable tool for identifying the resources which } \\
\text { are most sensitive to potential negative impacts } \\
\text { decreasing the connectivity between source areas } \\
\text { and other patches with suitable conditions for the } \\
\text { species }\end{array}$ & $\begin{array}{l}\text { Roberts AR,1991 } \\
\begin{array}{c}\text { L.E. Jackson, } \\
2004 \\
\text { Tran L, } 2009 \\
\text { Gon?Alves J, } \\
2016\end{array}\end{array}$ \\
\hline $\begin{array}{c}\text { Human- } \\
\text { natural } \\
\text { Vulnerability }\end{array}$ & $\begin{array}{l}\text { focus on economic } \\
\text { and political } \\
\text { response to the } \\
\text { climate change, } \\
\text { natural hazard or } \\
\text { social events }\end{array}$ & $\begin{array}{l}\text { characteristics of individuals determine their } \\
\text { capacity to react to threats of punctual character } \\
\text { the internal systems' susceptibility to specified } \\
\text { disturbances and its coping and adaptive capacity } \\
\text { towards the given pressure }\end{array}$ & $\begin{array}{l}\text { Eakin and Luers, } \\
\qquad 2006 \\
\text { Berrouet, 2018; } \\
\text { Johnson, } 2016\end{array}$ \\
\hline
\end{tabular}

Comparing the definitions of vulnerability from different perspectives, they are generally regarded as a valuable tool to assess the negative impacts, which is based on correct exposure to the risk sources and events (Hans Liwång, 2019). Considering the basic definition from IPCC, vulnerability is the extent to which fragile ecosystems are damaged or injured, depending on exposure, sensitivity and adaptive capacity (IPCC, 2014). The three key components are widely used in many vulnerability research-the function of a system's exposure to a driver, its sensitivity/susceptibility to such a driver, and its capacity to adapt to changes caused by exposure to the driver (Liverman D, 2008).In this research, rural LV is affected by the actual human-natural system of villages and reflects to the visual rural environment, which is evaluated to understand the degree to which the landscape receptors or characteristics are vulnerable to the risk sources or events. LV has a positive functional relationship with the system's exposure and sensitivity and has a negative impact on the adaptive capacity. These aspects are interpreted in this research as follows:

(1) Exposure means that "the system is subject to the risk source or hazard/threat" (Aven T, 2012), which reflects the extent in which rural landscape system is exposed to adverse disturbances, or in contact with a driver of change. 
(2) Sensitivity is the degree to which the rural landscape system is affected either adversely or beneficially, which reflects the set of conditions and characteristics of rural landscape following the exposure (F. Bousquet, 2015).

(3) Adaptive capacity reflects the potential of rural settlements to implement planned adaptation measure, to avoid or weaken the negative impact and protect the original landscape characteristics ( $\mathrm{N}$. Adger, 1999).

\subsection{Methods for Measuring Landscape Vulnerability}

A wide range of approaches have been used to assess landscape vulnerability including, for example, landscape pattern assessment with landscape pattern index and landscape vulnerability index (Cong $L \mathrm{~L}$, 2012). According to the current research, widely recognized index/factors of rural landscape vulnerability were selected through the actual Slovak law, including twelve essential landscape receptors. The model set of crucial vulnerability criteria (Table 2) was evaluated combined with various methods of environmental vulnerability evaluation and the needs of rural construction respecting the local customs and environmental conditions (William K D, 2016).

Table 2. The model set of rural landscape vulnerability criteria as aggregated.

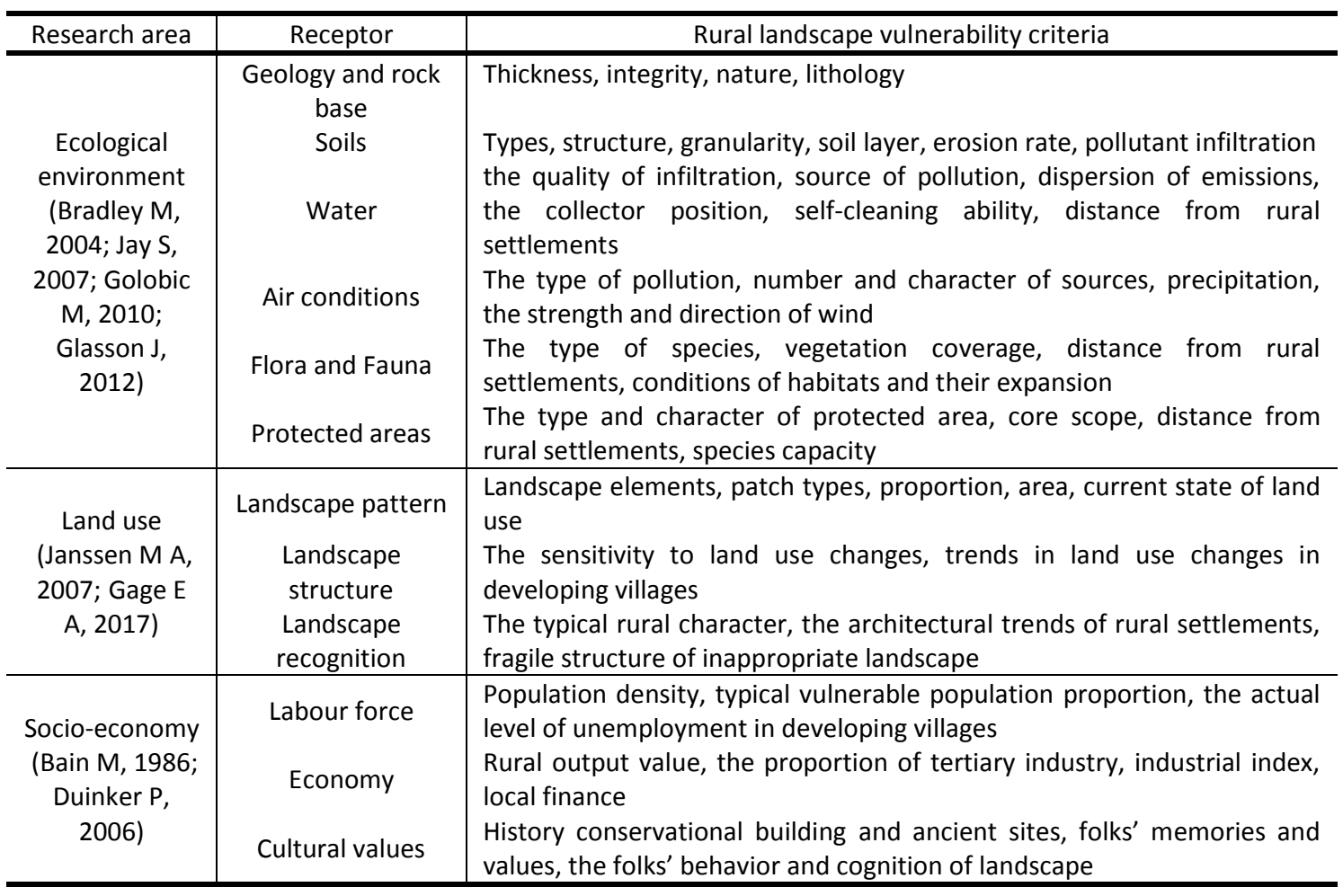

Vulnerability evaluation has mainly focused on either subjective or objective evaluation models with evaluation index (Boori M S, 2015). Among them, analytic hierarchy process (AHP), principle component analysis and entropy method are the most common models used in vulnerability evaluation, with establishment of judgment consistency matrix. Some scholars even defined vulnerability as a function of Exposure, Sensitivity and Adaptive capacity (Chen S, 2019), as generally expressed in Eq.(1) or Eq.(2).

$V=\frac{\text { Exposure } \times \text { Sensitivity }}{\text { Adaptive capacity }}$ 
$V=$ Exposure + Sensitivity - Adaptive capacity

\section{Construct a Framework for Rural Landscape Vulnerability}

\subsection{Three components}

Linkages with the sub-systems of rural landscape vulnerability, each here can be divided to exposure, sensitivity and adaptation, and assessed using spatially-explicit indicators (Table 3). Ecological environment vulnerability is more affected by exposure (i.e., geology, soils, water and climate), and exists obvious sensitivity which is vulnerable to the disturbances from natural change or human activities. Land use vulnerability originates from exposure, sensitivity and adaptation to the incontrollable landscape structure. Socio-economic vulnerability is more considered from the combination of exposure, sensitivity and adaptation, according to the extent of social and economic development.

Table 3. Description of the components of rural landscape vulnerability.

\begin{tabular}{c|c|l}
\hline Sub-system & $\begin{array}{c}\text { Vulnerability } \\
\text { component }\end{array}$ & \multicolumn{1}{c}{ Description } \\
\hline $\begin{array}{c}\text { Ecological } \\
\text { environment }\end{array}$ & $\begin{array}{c}\text { Exposure } \\
\text { Sensitivity } \\
\text { Adaptation }\end{array}$ & $\begin{array}{l}\text { Exposure of rural base environment to the disturbances } \\
\text { Sensitivity of eco-system and disturbance types } \\
\text { Resilience of eco-system, eco-restoration technology and } \\
\text { management }\end{array}$ \\
\hline \multirow{2}{*}{ Land use } & Exposure & $\begin{array}{l}\text { Structure of land use when exposes in different geological and } \\
\text { production types } \\
\text { Rural build environment and landscape fragmentation } \\
\text { Sand arragement and government with reasonable land division }\end{array}$ \\
\hline \multirow{2}{*}{ Socio-economy } & Edaptation & $\begin{array}{l}\text { Exposure of rural population density and assets } \\
\text { The amout of typical vulnerable folks and imbalance industrial } \\
\text { structure } \\
\text { Siscrimative resources to minimize the negative effect of human } \\
\text { ecomomic activities }\end{array}$ \\
\hline
\end{tabular}

\subsection{Temporal and spatial Dimensions}

Linkages with the sub-systems of rural landscape vulnerability, each here can be divided to exposure, sensitivity and adaptation, and assessed using spatially-explicit indicators (Table 3). Ecological environment vulnerability is more affected by exposure (i.e., geology, soils, water and climate), and exists obvious sensitivity which is vulnerable to the disturbances from natural change or human activities. Land use vulnerability originates from exposure, sensitivity and adaptation to the incontrollable landscape structure. Socio-economic vulnerability is more considered from the combination of exposure, sensitivity and adaptation, according to the extent of social and economic development.

Rural landscape is a complex system with multi-level and multi-dimensional, and its vulnerability will be researched from spatial and temporal dimensions.

In spatial dimension, rural landscape vulnerability is disturbed by different scales such as global, national, regional, county, town and village (Sun P, 2010). At different spatial scales, the disturbance sources of rural landscape vulnerability determine the specific manifestations (Fig. 1). For example, climate change indirectly affects rural landscape vulnerability at global scale, while heavy rainfall at regional scale will directly affect rural landscape exposure. In addition, the vulnerability factors of rural landscape will also change in different spatial scales. For example, the vulnerability factors of rural economic landscape focus 
on the total population and economy at the national scale, but become the average income of farmers at the village scale.

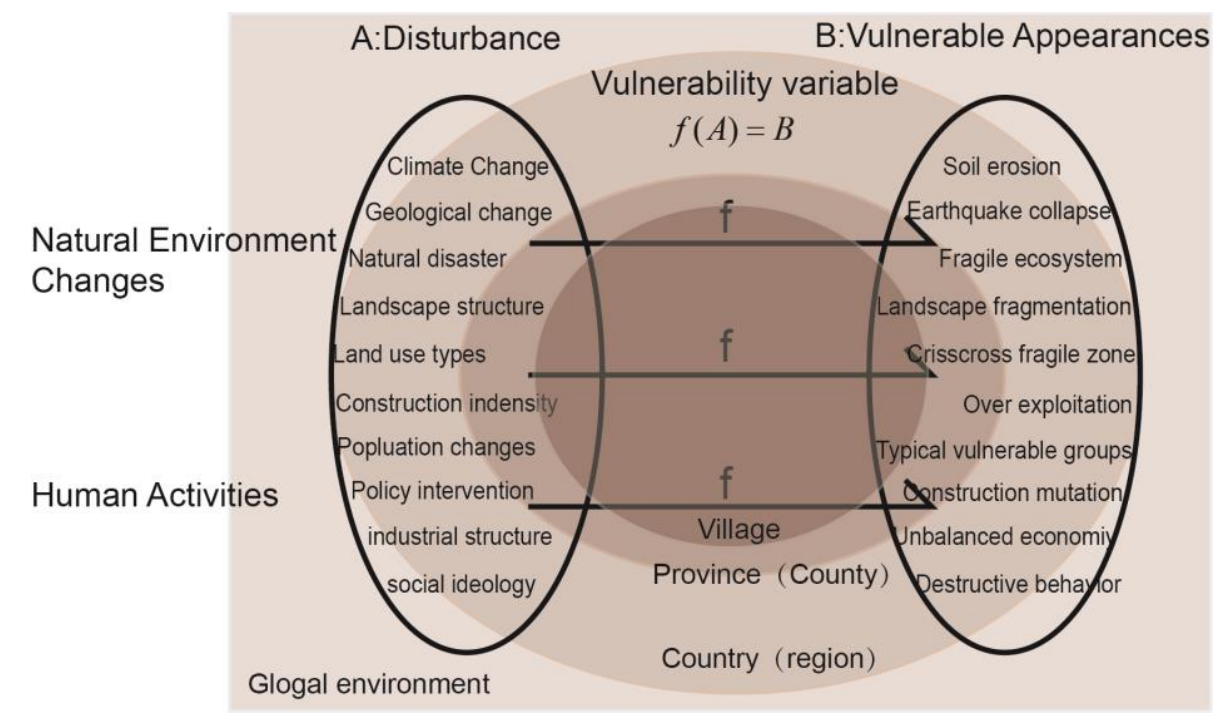

Figure 1. Analysis of rural landscape vulnerability appearances.

In temporal dimension, rural landscape vulnerability is affected by long-term potential disturbance sources and sudden disturbance sources. The long-term potential disturbance source reflects the inherent vulnerability development law of rural landscape in a certain time, so as to judge the main vulnerability factors of rural human-natural system in the three components of exposure, sensitivity and adaptability, and provide the basis for adjusting the orientation and direction of rural development. Sudden disturbance sources refer to sudden disasters in rural areas, which can reflect the sensitivity extent and adaptability of rural human-natural system to sudden events.

\subsection{Three components}

Combined with the analytical framework, the research of rural landscape vulnerability should focus on four segments, disturbances, components, evaluation and representation. From the generating logic of rural landscape vulnerability, this paper proposes the research framework to present the study procedure of quantitatively and comprehensively finding the vulnerable sources and levels in developing villages (Fig. 2). 


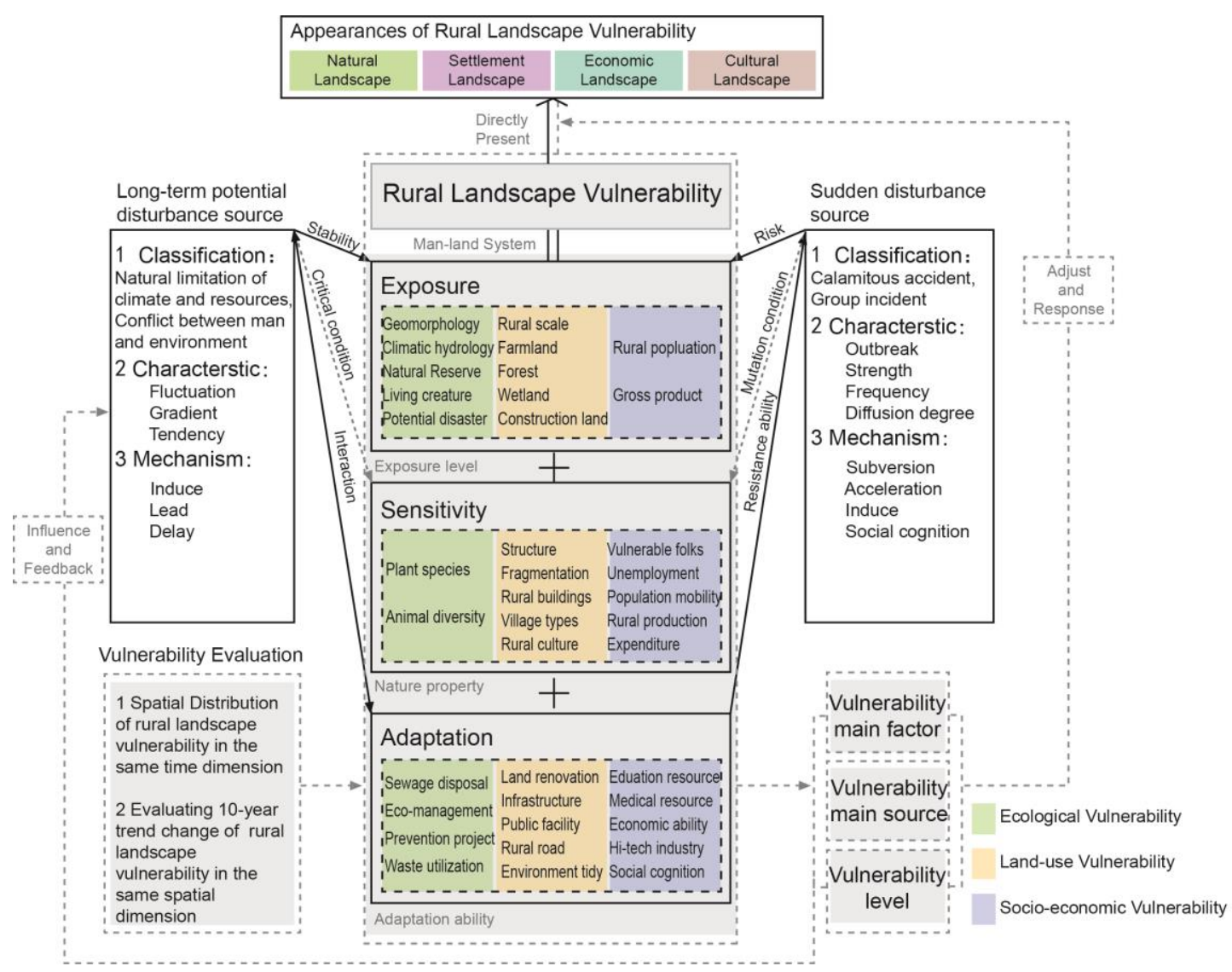

Figure 2. Research framework of rural landscape vulnerability.

\subsection{Evaluation method}

Rural landscape vulnerability index can be established based on landscape vulnerability evaluation index, increasing the relevant index which reflects the characteristics of rural human-natural, as shown in Fig. 3. This paper takes exposure, sensitivity and adaptability as standard level, ecological environment, land use and social economy as factor level, and vulnerability factors as variable level. In addition, the impact of indicators on vulnerability can be divided into positive and negative: the increase of positive indicators will enhance the vulnerability, and vice versa.

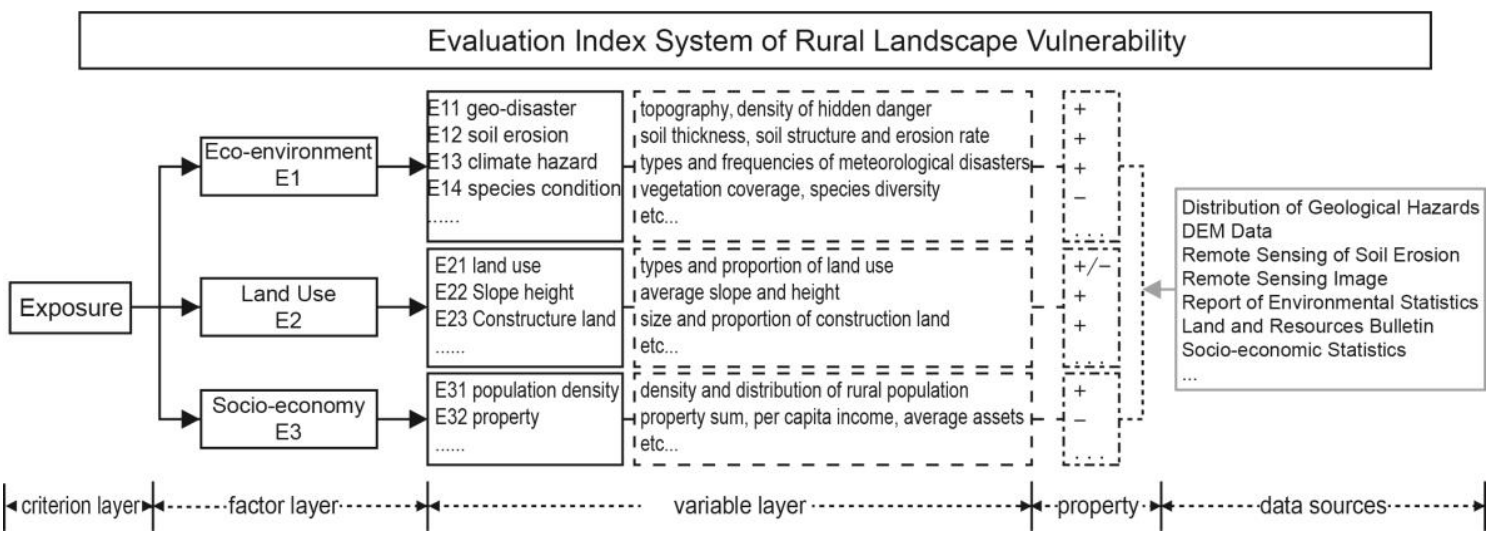

Figure 3. Mode of evaluation index system of rural landscape vulnerability (Exposure Criterion Level). 
As discussed in the previous literature, vulnerability is generally regarded as a function of Exposure, Sensitivity and Adaptive capacity. This study adopts a common model to express the LV using Eq. (8), which is calculated using dimension scores, measuring the $\mathrm{LV}$ of each village sample relative to other villages on a linear scale (Tian Y, 2013). In Eq. (3), LVh refers to the vulnerability extent of village sample $h$, where Eh represents the Exposure dimension score of village sample $h$, where Sh refers to the Sensitivity dimension score of village sample $h$, and where ACh is the Adaptive Capacity dimension score of village sample h.

$$
L V_{h}=E_{h}+S_{h}-A C_{h}
$$

As discussed in the previous section normalized values of indicators for different components are combined to calculate dimension scores using Eq. (4). Where $B_{i}$ represents the percentage of variance explained by factor $i$, where $i$ ranges from 1 to $n$, where $n$ is the total number of factors resulting from factor analysis. $C_{h i}$ refers to the component score coefficient of village sample $\mathrm{h}$ for factor $\mathrm{i}$.

$$
E_{h}\left(\text { or } S_{h} \text { or } \mathrm{AC}_{h}\right)=\sum_{i=1}^{n} B_{i} C_{h i}
$$

In order to reflect results of LVrs on a linear scale, these results should be standardized using Eq. (5), where $S L V_{h}$ refers to the standardized $L V$ values of village sample $h$, where $L V_{\min }$ is the least value of $L V$ and $L V_{\max }$ is the largest value of LV observed over 12 village samples. The standardization process calibrates the LVrs values on a 0-1 scale, for easy comparison.

$$
S L V_{h}=\frac{L V_{h}-L V_{\text {min }}}{L V_{\max }-L V_{\min }}
$$

\section{Case studies results and analyses}

\subsection{Study Area}

Linkages with the sub-systems of rural landscape vulnerability, each here can be divided to exposure, sensitivity and adaptation, and assessed using spatially-explicit indicators (Table 3). Ecological environment vulnerability is more affected by exposure (i.e., geology, soils, water and climate), and exists obvious sensitivity which is vulnerable to the disturbances from natural change or human activities. Land use vulnerability originates from exposure, sensitivity and adaptation to the incontrollable landscape structure. Socio-economic vulnerability is more considered from the combination of exposure, sensitivity and adaptation, according to the extent of social and economic development.

We choose three counties in Heilongjiang Province of China to be the empirical objects in this paper, where has huge village base, varied eco-environment, diversified land use and socio-economic development in rural area. Considering the comprehensive conditions in Heilongjiang, we pick Jixian County (latitude $46.7^{\circ}$, longitude $131.1^{\circ}$ ) as typical counties, which is a typical affluent area with rich natural, agricultural and tourism resources, including 8 townships and 336 villages. To pick the typical village samples on rural landscape investigation, we set the standard criteria for selection, see Table 4.

Table 4. The selection criteria of typical village samples in Jixian County

Selection Element $\quad$ Selection Criteria




\begin{tabular}{|c|c|}
\hline & registration population) \\
\hline Natural Resource & $\begin{array}{l}\text { Select villages with different resource base, like cultivated land, water, geography } \\
\text { and climate conditions }\end{array}$ \\
\hline Land Use & $\begin{array}{l}\text { Select villages with different land utilization, containing diversity land use and simple } \\
\text { type }\end{array}$ \\
\hline Economic Level & $\begin{array}{l}\text { Select villages with varied economic situation, including those with strong economic } \\
\text { conditions, and those with lower economic conditions and greater potential for } \\
\text { development }\end{array}$ \\
\hline Distributive Condition & $\begin{array}{l}\text { Select villages with the consideration of distance between village and city, including } \\
\text { inside the cities, near the cities and far away from city }\end{array}$ \\
\hline Construction & $\begin{array}{l}\text { Select villages with the consideration of rural infrastructure and public facilities, } \\
\text { including complete ones and incomplete ones }\end{array}$ \\
\hline National Custom & $\begin{array}{l}\text { Select villages which contains Han nationality villages, minority autonomous villages } \\
\text { and mixed villages }\end{array}$ \\
\hline Rural Characteristics & $\begin{array}{l}\text { Select counties with distinct landscape characteristics and local representative, such } \\
\text { as famous historical villages, Traditional Chinese Villages and so on }\end{array}$ \\
\hline
\end{tabular}

Combining with sample selection criteria, we pick 12 samples in Jixian County (Fig. 4).
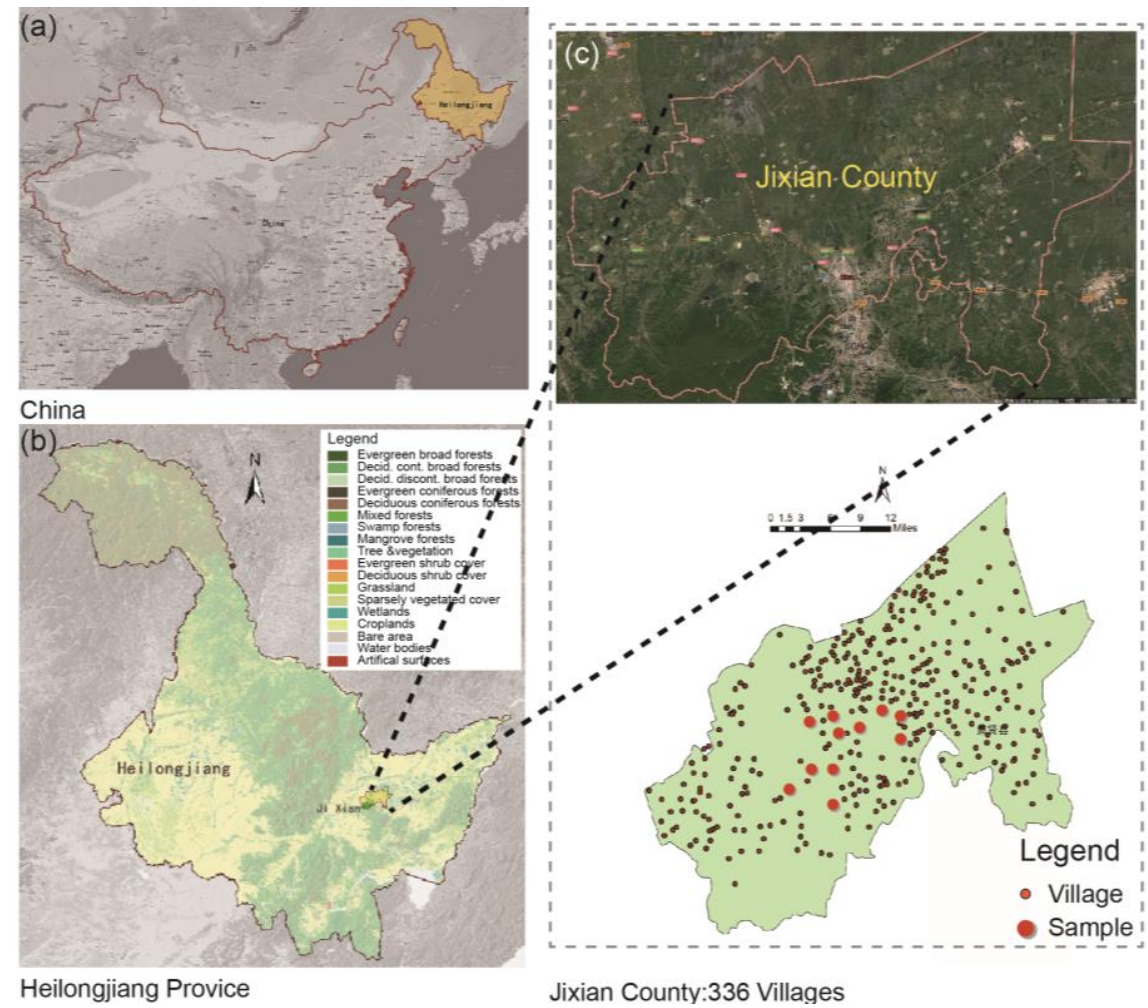

Jixian County:336 Villages

Figure 4. Study area: (a) the geographical position of Heilongjiang in China; (b) the different subregions of landcover of Jixi County in Heilongjiang; (c) the distribution of 12 village samples

\subsection{Selections and Pretreatment of Data}

This study was based on statistic data, spatial data and primary data, which are collected as follows:

(1) Statistic data mainly reflects basic ecological environment, rural economic and social situation. Geological data were from soil monitoring data of Heilongjiang Institute of Environmental Sciences, and climatic data were from Heilongjiang Meteorological Bureau. Some social and economic data were from statistical results of 12 village committees in 2018, like population, average income, financial support and infrastructure project. 
(2) Spatial data was used to describe objects to show the distribution characteristics of spatial entities, including the size of geological hazard, village accessibility and land utilization. The data of geological hazards were from the distribution map of landslides in Heilongjiang Land and Resources Department. Land use data were calculated from 2018 remote sensing images of Heilongjiang Province (Landsat 8 OLI, resolution $30 \mathrm{~m}$ ).

(3) Primary data contained on-the-spot investigation and questionnaire. We chose 600 villagers to make the interviews and questionnaires, with different age, career, income and education, to collect and analyze villagers' cognition of rural landscape.

\subsection{Estimated Values of Rural Landscape Vulnerability}

This paper uses SPSS 22.0 software to calculate the factor eigenvalues, variance contribution and principal factor load matrix of exposures, sensitivity and adaptability, with the indicators of 12 village unit. In the factor analysis of exposure, sensitivity and adaptability, dimensionless data passed KMO test and scored $0.612,0.625$ and 0.842 , which all met the preconditions of principal component analysis. The standardized thresholds of rural landscape vulnerability are shown in Table 5.

Table 5. Estimated values for landscape vulnerability of village samples and its dimensions.

\begin{tabular}{lllll}
\hline \multirow{2}{*}{ Village } & \multicolumn{3}{c}{ Component } & \multicolumn{2}{c}{$\begin{array}{c}\text { Landscape } \\
\text { Vulnerability }\end{array}$} \\
\cline { 2 - 5 } & Exposure & Sensitivity & Adaptation & 0.322 \\
Jiaxinzi Village & 0.000 & 0.584 & 0.628 & 0.305 \\
Xuma Village & 0.001 & 0.561 & 0.642 & 0.825 \\
Fangsheng Village & 0.286 & 0.684 & 0.000 & 0.092 \\
Xinxing Village & 0.116 & 0.375 & 1.000 & 0.203 \\
Xingguo Village & 0.004 & 0.294 & 0.584 & 0.627 \\
Nanli Village & 0.231 & 0.710 & 0.371 & 0.688 \\
Lizhong Village & 0.303 & 0.761 & 0.371 & 0.557 \\
Taiping Village & 0.212 & 0.580 & 0.362 & 0.667 \\
Dongfa Village & 0.527 & 0.674 & 0.551 & 0.633 \\
Donghui Village & 0.434 & 1.000 & 0.852 & 0.743 \\
Dongrong Village & 0.595 & 0.663 & 0.455 & 0.826 \\
Dongxing Village & 0.776 & 0.641 & 0.445 & \\
\hline
\end{tabular}

In order to visualize the landscape vulnerability of sample villages, this paper uses ArcGIS 10.3 to assign vulnerability values to 12 villages, and adopts the natural breakpoint classification method to divide them into five levels, which are Serious, High, Moderate, Low and Very Low, as shown in Table 6.

Table 6. Vulnerability evaluation levels of villages and description of vulnerability level.

\begin{tabular}{|c|c|c|c|}
\hline $\begin{array}{l}\text { Vulnerability } \\
\text { Level }\end{array}$ & $\begin{array}{l}\text { Village } \\
\text { Amount }\end{array}$ & $\begin{array}{l}\text { Village } \\
\text { Proportion }\end{array}$ & Description of Vulnerability Level \\
\hline Very Low & 1 & $8 \%$ & $\begin{array}{l}\text { flat terrain, good ecological environment, prefect facilities, complete } \\
\text { culture, diversity product and affluent life }\end{array}$ \\
\hline Low & 0 & 0 & $\begin{array}{l}\text { certain ecological resource, strong construction and transformation, good } \\
\text { building landscape, adequate income }\end{array}$ \\
\hline Moderate & 4 & $34 \%$ & $\begin{array}{l}\text { adequate infrastructure, incomplete environment and building } \\
\text { transformation, low vitality, simple industry structure }\end{array}$ \\
\hline High & 5 & $42 \%$ & $\begin{array}{l}\text { incomplete facilities and environmental improvement, dilapidated } \\
\text { buildings, lost custom culture, poor agricultural economy }\end{array}$ \\
\hline Serious & 2 & $16 \%$ & $\begin{array}{l}\text { rare facilities and environmental improvement, damaged buildings, } \\
\text { frequent disasters, poor economy }\end{array}$ \\
\hline
\end{tabular}

The spatial distribution characteristics of rural landscape vulnerability includes (Fig. 5): (1) the villages with rare natural environment resource and single industrial structure have higher landscape 
vulnerability, and (2) the administration villages, minority villages and remote villages have higher landscape vulnerability.

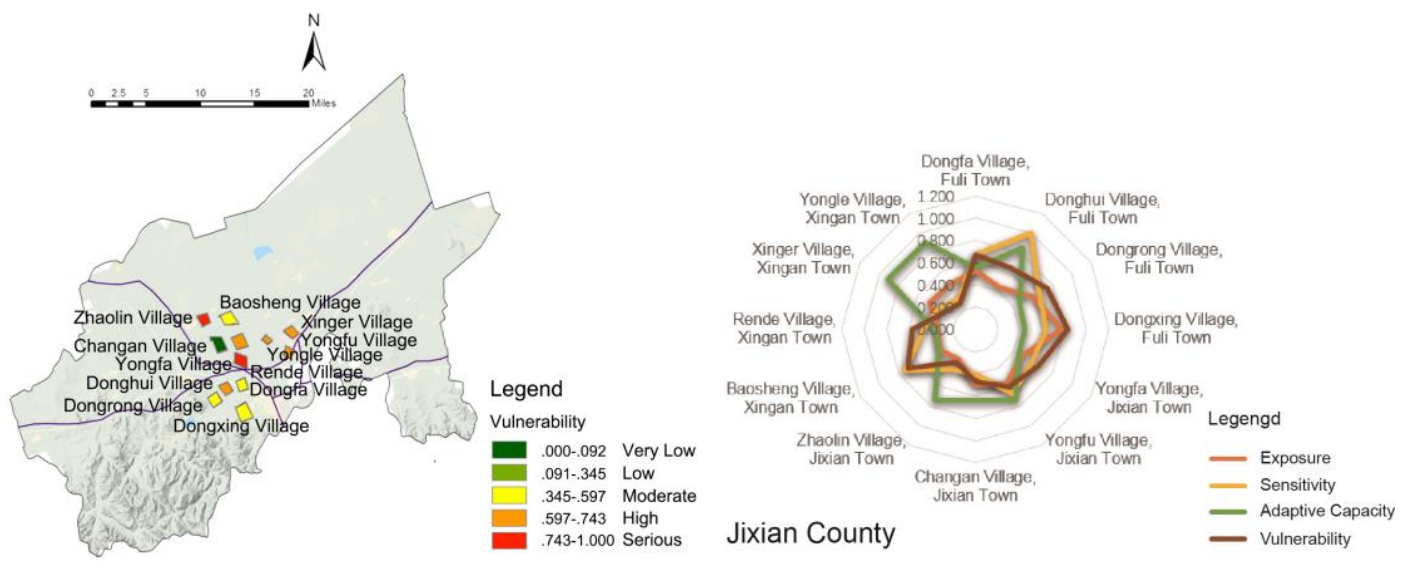

Figure 5. Spatial distribution of rural landscape vulnerability and comparison among estimated values

\subsection{Rural Planning Strategies}

In this study, 12 sample villages can be divided into 3 main categories to propose rural planning strategies for the construction of liveable settlement environment, named C1, C2 and C3, which are interpreted as follows:

(1) C1. In the traditional village classification, security type refers to poor, remote, and scruffy villages, that are high vulnerability units because of high exposure and sensitivity and low adaptive capacity. To decline or cope with the value of LVrs, the government needs to control the extension of construction land, protect the ecological conversation and unutilized land, and provide employment opportunities to young folks, thus helping reduce the impact of exposure.

(2) C2. It refers to the villages that have completed infrastructure construction with certain economic conditions and mainly show high or serious vulnerability because of high sensitivity and moderate adaptive capacity. The government should provide economic and technological support to promote agricultural facilities, irrigation conditions, and rural traffic, which can also improve the environment and farm maintenance and increase farming income to reduce the sensitivity and promote adaptive capacity.

(3) C3. It refers to villages with better natural resources, land use, and economic foundation. In this type, villages are the most normal or low Vulnerability ones because of low exposure and high adaptive capacity. The planning strategies should enhance control of land use and decline fragmentation through farmland renovation and restoration of abandoned land on the one hand. On the other hand, landscape designers should attempt to integrate traditional culture into buildings, public spaces, and even architectural components.

\section{Conclusion}

In this paper, the vulnerability evaluation of rural landscape is constructed from three vulnerability components of exposure, sensitivity and adaptation, so as to analyze the vulnerability source of rural landscape system, calculate its vulnerability threshold, and provide scientific support for the planning strategies of rural landscape construction through its principle factors. According to the assessment results of 12 typical villages, $58 \%$ village samples are high or serious vulnerability settlements with high exposure to the changes of land use and population. Further, the rural planning strategies were proposed 
to cope with the landscape vulnerability, improving the construction for liveable settlement environment, according to the vulnerability levels. This research can aid decision makers in reducing the future negative impact which village landscape may suffer due to different risk resources and hazards/threats.

\section{Funding}

This research was funded by the National Key R\&D Program of China (Project No. 2018YFC0704705), the 66th China Postdoctoral Science Foundation (Project No. 2019M661284), Heilongjiang Province Socialscience Research Project (Project No. 20SHC179) and Heilongjiang Province Art Science Planning Project (Project No. 2020C020).

\section{References}

Appleton K, Lovett A , Gilla Sünnenberg, et al. (2002) Rural landscape visualisation from GIS databases: a comparison of approaches, options and problems, Computers, Environment and Urban Systems, 26(3), p141-162.

Aven T. (2012) On the link between risk and exposure, Reliability Engineering \& System Safety, 106, p191199.

Bain M, Irving J, Olsen R, Stull E, Witmer G. (1986) Cumulative impact assessment: evaluating the environmental effects of multiple human developments. Illinois: Argonne National Laboratory.

Boori M S, Vozenilek V, Choudhary K. (2015) Exposer Intensity, Vulnerability Index And Landscape Change Assessment In Olomouc, Czech Republic, ISPRS - International Archives of the Photogrammetry, Remote Sensing and Spatial Information Sciences, 73(7), p771-776.

Bradley M, Smith E. (2004) Using science to assess environmental vulnerabilities, Environmental Monitoring \& Assessment, 94, p1-7.

Cong L L , Jiang D , Feng D Q . (2012) The New Rural Landscape Architecture Research Basing on the Background of Low Carbon Economy, Advanced Materials Research, 524-527, p3701-3704.

Chen S, Zha X, Bai Y, et al. (2019) Evaluation of soil erosion vulnerability on the basis of exposure, sensitivity, and adaptive capacity: A case study in the Zhuxi watershed, Changting, Fujian Province, Southern China, Catena, 177, p57-69.

Duinker P, Greig L. (2006) The impotence of cumulative effects assessment in Canada: ailments and ideas for redeployment, Environmental Management, 37(2), p153-61.

Drdos J, Hrnciarova Z. (2003) The evaluation of landscape carrying capacity in Slovakia. The international workshop of impact assessment, February 24-27. Slovakia: Teplý: Slovak Environmental Agency.

F. Bousquet, M. Anderies, M. Antona, et al. (2015) Social-ecological theories and empirical research. Comparing social-ecological schools of thoughts in action

Glasson J, Therivel R, Chadwick A. (2012) Introduction to environmental impact assessment. London: Oxford Brookes University.

Gage E A, Cooper D J. (2017) Relationships between landscape pattern metrics, vertical structure and surface urban Heat Island formation in a Colorado suburb, Urban Ecosystems, 20(6), p1-10.

GonAlves J , Honrado J P , Vicente J R, et al. (2016) A model-based framework for assessing the vulnerability of low dispersal vertebrates to landscape fragmentation under environmental change, Ecological Complexity, 28(12), p174-186.. 
H. Eakin, A.L. Luers. (2006) Assessing the vulnerability of social-environmental systems, Annual Review of Environment and Resources, 31, p 365-394.

Hessburg P F, Smith B G, Miller C A, et al. (1999) Modeling Change in Potential Landscape Vulnerability to Forest Insect and Pathogen Disturbances: Methods for Forested Subwatersheds Sampled in the Midscale Interior Columbia River Basin Assessment. Portland, Or. : U.S. Dept. of Agriculture, Forest Service, Pacific Northwest Research Station.

Hans Liwång. (2019) Exposure, vulnerability and recoverability in relation to a ship's intact stability, Ocean Engineering, 187, p33-35.

IPCC. Climate Change 2014. Synthesis Report Summary Chapter for Policymakers. New York.

Jay S, Jones C, Slinn P,Wood CH. (2007) Environmental impact assessment: retrospect and prospect. Environmental Impact Assessment Review, 27(4), p287-300.

J.E. Johnson, D.J. Welch, J.A. Maynard. (2016) Assessing and reducing vulnerability to climate change: moving from theory to practical decision-support, Marine Policy, 74(12), p220-229.

Janssen M A. (2007) An Update on the Scholarly Networks on Resilience, Vulnerability, and Adaptation within the Human Dimensions of Global Environmental Change, Global Environmental Change, 16(3), p240-252.

L.E. Jackson, S.L. Bird, R.W. Matheny. (2004) A regional approach to projecting land-use change and resulting ecological vulnerability, Environmental Monitoring and Assessment volume, 94, p231248.

L.M. Berrouet, J. Machado, C. Villegas-Palacio. (2018) Vulnerability of socio-ecological systems: a conceptual framework, Ecological Indicator, 84, p632-647.

Liverman D. (2008) Assessing impacts, adaptation and vulnerability: Reflections on the Working Group II Report of the Intergovernmental Panel on Climate Change, Global Environmental Change, 18(1), p0-7.

N. Adger. (1999) Social vulnerability to climate change and extremes in Costal Vietnam, World Development, 27(12), p249-269.

Peter Weißhuhn. (2019) Regional assessment of the vulnerability of biotopes to landscape change, Global Ecology \& Conservation, 20 [online] https://www.sciencedirect.com/science/article/pii/S2351989419302094 (Accessed: 31 August 2019)

Roberts AR. (1991) Just what is EIR? 1st ed. California: Global Environmental Management. Service.

Sauer, C. O. (1925) The Morphology of Landscape. University of California Publications in Geography, p1953.

Sun P, Xiu C. (2010) Coupling Degree Assessment of the Man-Land Coupling System of the Mining City from the Vulnerability Perspective, Areal Research \& Development, p65-72.

Schneiderbauer S, Ehrlich D. (2004) Risk, hazard and people's vulnerability to natural hazards: A Review of Definitions. European Communities Press.

Toro J, Requena I, Zamorano M. (2010) Environmental impact assessment in Colombia: critical analysis and proposals for improvement. Environmental Impact Assessment Review, 30(4),p247-261. 
Tran L, O'Neil R, Smith E. (2009) Determine the most influencing stressors and the most susceptible resources for environmental integrated assessment, Ecological Modelling, 220(18), p2335-2340.

Tian Y, Xiang Q, Wang P. (2013) Regional coupled human-natural systems vulnerability and its evaluation indexes, Geographical Research, 32(1), p55-63.

William K D, Elizabeth A O. (2016) Climate change and rural communities in Ghana: Social vulnerability, impacts, adaptations and policy implications, Environmental Science \& Policy, 55, p208-217. 